\title{
Vliv kombinovaného vytrvalostního/silového tréninku na variabilitu srdeční frekvence u mužủ s chronickou ischemickou chorobou srdeční
}

\section{Effect of Combined Endurance/Strength Training on Heart Rate Variability of Men with Chronic Coronary Artery Disease}

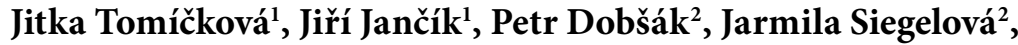 \\ Roman Panovský ${ }^{3}$
}

\author{
Fakulta sportovních studií Masarykovy univerzity, Brno ${ }^{1}$ \\ Klinika funkční diagnostiky a rehabilitace ${ }^{2}$ a I. kardio- \\ angiologická klinika LF MU, FN u sv. Anny v Brně ${ }^{3}$
}

\begin{abstract}
Abstrakt
31 mužu s chronickou ischemickou chorobou srdeční (průměrný věk $64 \pm 11$ let, průmèrná váha $83 \pm$ $10 \mathrm{~kg}$, průměrná výška $177 \pm 6 \mathrm{~cm}$, průměrná ejekční frakce levé komory srdeční $47 \pm 11 \%$ ), bylo vyšetřeno prè a po tři měsíce trvajícím aerobním tréninku kombinovaném (od třetího týdne) se silovým cvičením. Symptomy limitovaná spiroergometrie byla provedena před a po tréninkové periodè. Trénink (tréninková jednotka) byla prováděna třikrát týdně. Před zátěžovým testem byla provedena krátkodobá analýza variability srdeční frekvence. Ukazatelé $H R V$ ve frekvenční doméně byly získány ráno v klidu při metronomem kontrolovaném dýchání. Celkový spektrálni výkon (TP), spektrální výkon v nízkofrekvenčním (LF, 0,05-0,15 Hz) a spektrální výkon ve vysokofrekvenčním (HF, 0,15-0,5 Hz) pásmu spektra a jejich vzájemný poměr (LF/HF) byly měreny v průběhu 5minutového monitorování. Dvanáct týdnů trvající kombinovaný vytrvalostní/silový trénink zvýšil HRV (HF, LF a TP) u mužů se stabilní chronickou ischemickou chorobou srdeční.
\end{abstract}

\begin{abstract}
s
31 men with chronic coronary artery disease (mean age $64 \pm 11$ years, mean body weight $83 \pm 10 \mathrm{~kg}$, mean height $177 \pm 6 \mathrm{~cm}$, mean ejection fraction of left heart ventricle $47 \pm 11 \%)$, were examined before and after three months lasting aerobic training combined (from $3^{\text {rd }}$ week) with strength training.

Symptom-limited spiroergometry was provided before and after the training period. The training (exercise unit) was performed three times a week. Before exercise testing, short-term heart rate variability (HRV) analyses of all subjects were obtained. Frequency domain HRV indexes were determined in the morning during quiet periods under metronome controlled breathing. Total power (TP), low-frequency spectral component $\mathrm{HRV}(\mathrm{LF}, 0,05-0,15 \mathrm{~Hz})$, high-frequency spectral component $\mathrm{HRV}(\mathrm{HF}, 0,15-0,5 \mathrm{~Hz})$ and lowfrequency-to-high frequency (LF/HF) ratio were measured for 5 minutes in the monitoring. Twelve weeks lasting combined endurance/strength training increased HRV (HF, LF and TP) in men with stable chronic coronary disease.
\end{abstract}

Klíčová slova: Variabilita srdeční frekvence, kombinovaný trénink, chronická ischemická choroba srdeční

Key words: $\quad$ Heart rate variability, combined training,, chronic coronary artery disease

Podporováno grantem IGA NS/10096-4.

\section{ÚVOD}

Řadu let je známa skutečnost, že srdeční rytmus není za fyziologických podmínek zcela pravidelný. Analýza variability srdečního rytmu se však stala populární metodou kardiovaskulárního výzkumu až $\mathrm{v}$ poslední době. Kardiovaskulární funkce jsou ovlivněny rovnováhou mezi sympatickou a parasympatickou aktivitou. Zvýšená aktivita sympatiku je spojena se zvýšeným rizikem srdečních př́hod, zejmé- 
na u nemocných s prokázanou ischemickou chorobou srdeční. Při měření variability srdeční frekvence byla zjištěna vyšší parasympatická aktivita fyzicky trénovaných osob ve srovnání s netrénovanými a zvýšení variability srdeční frekvence po tréninku u pacientů s chronickou ischemickou chorobou srdeční (Chaloupka 2003).

Většina tréninkových aktivit, včetně rehabilitačních programů $\mathrm{v}$ dříve publikovaných pracích (Okazaki 2005, Jančík 2002), byla založena pouze na aerobním způsobu zátěže. Teprve v současné době se v literatuře objevují práce hodnotící změny variability srdeční frekvence v průběhu nebo bezprostředně po ukončení cvičení se setrvávající statickou zátěží nebo dynamickou odporovou zátěží vyšší intenzity s dominujícím anaerobním způsobem krytí energetických požadavků (Lee 2006, Rezk 2006). V dostupné literatuře jsme zatím nenašli dostatek validních informací týkajících se vlivu silového nebo dlouhodobého kombinovaného tréninku na variabilitu srdeční frekvence nemocných s chronickou ischemickou chorobou srdeční.

\section{CÍL PRÁCE}

Posoudit vliv dvanáctitýdenního kombinovaného vytrvalostního/silového tréninku na variabilitu srdeční frekvence u nemocných s chronickou ischemickou chorobou srdeční.

\section{METODIKA}

Do studie bylo zařazeno celkem 31 mužů s chronickou ischemickou chorobu srdeční v I. a II. funkční třídě dle NYHA. Za průkaz ICHS jsme považovali koronarograficky verifikovanou hemodynamicky významnou stenózu alespoň jedné koronární tepny nebo enzymaticky potvrzený infarkt myokardu v anamnéze. Průměrná EF levé komory v souboru byla $47 \pm 11 \%$, věk $64,4 \pm 11,3$ roků. Průměrná hmotnost $82,7 \pm 9,8 \mathrm{~kg}$. Standardní medikamentózní léčba mezi vyšetřeními sestávala $\mathrm{z}$ ACE inhibitorů, diuretik, nitrátů a betablokátorů $\mathrm{v}$ kombinacích a nebyla během rehabilitačního programu měněna.

\section{Měření variability srdeční frekvence}

Vyšetření probíhalo $\mathrm{v}$ dopoledních hodinách $\mathrm{v}$ klidném a tichém prostředí ambulance Kliniky funkční diagnostiky a rehabilitace Fakultní nemocnice u sv. Anny v Brně. Srdeční frekvence byla měřena tep po tepu jako R-R interval nejméně po 5 minutách klidu vleže, kdy už nedocházelo $\mathrm{k}$ dalšímu pozorovatelnému poklesu srdeční frekvence. Byly snímány a zaznamenávány délky R-R intervalů 5 minut vleže, následovalo postavení, kdy byl po relativním zklidnění (15-20 s) pořízen druhý pětiminutový záznam. Ve vlastní práci jsme hodnotili krátkodobou variabilitu srdeční frekvence získanou po opětovném položení, zklidnění se stabilizací srdeční frekvence, při metronomem kontrolované frekvenci dýchání $0,33 \mathrm{~Hz}$ prrístrojem VariaPulse TF-3 Sima Media Olomouc po dobu dalších 5 minut. Přístroj umožňuje zobrazení a archivaci průběhu srdeční frekvence v čase a provedení spektrální analýzy rychlou Fourierovou transformací. Měření byla provedena před započetím a po skončení dvanáctitýdenního tréninkového programu. Metodou frekvenční (spektrální) analýzy jsme hodnotili celkový spektrální výkon (TP-total power), spektrální výkon v nízkofrekvenčním pásmu spektra (LF, 0,05-0,15Hz), spektrální výkon ve vysokofrekvenčním pásmu spektra (HF, $0,15-0,5 \mathrm{~Hz})$ a poměr nízkofrekvenčního a vysokofrekvenčního spektrálního výkonu (LF/HF).

Metodou časové analýzy byla hodnocena průměrná délka R-R intervalu a průměrná hodnota druhých mocnin rozdílů délek sousedních R-R intervalů - MSSD. 

frekvence u mužů s chronickou ischemickou chorobou srdeční

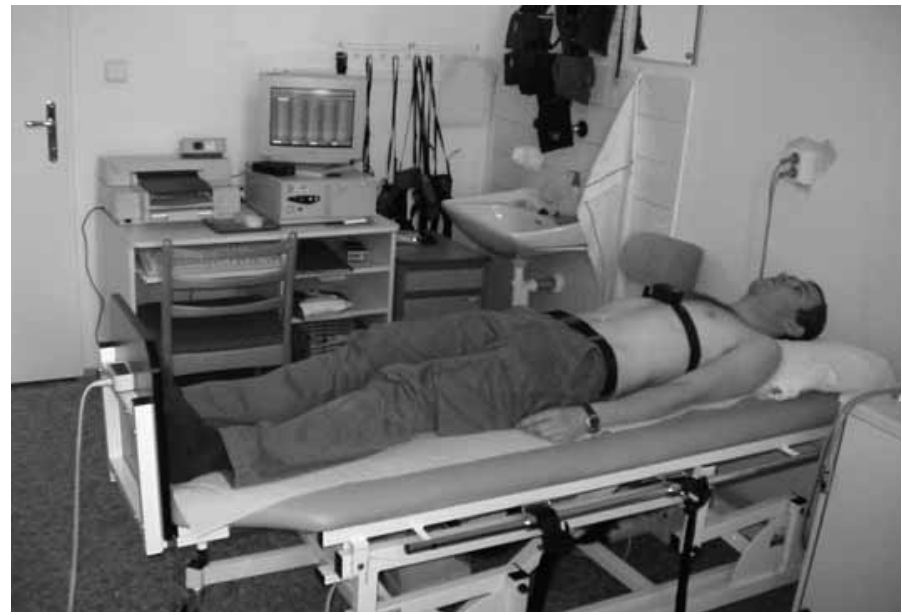

Obr. 1 Vyšetření variability srdeční frekvence př́strojem VariaPulse TF-3 Sima Media

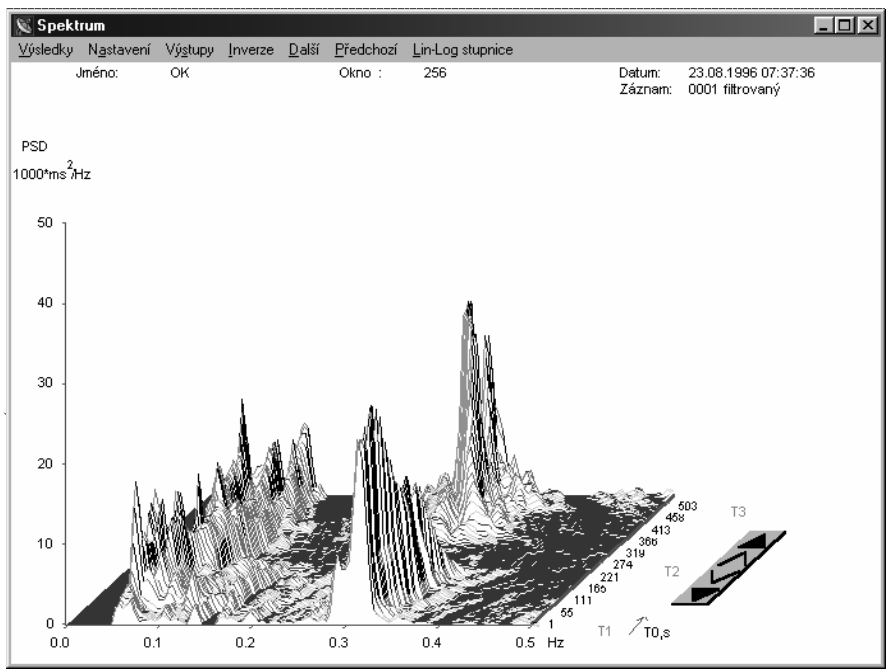

Obr. 2 Záznam spektrální analýzy variability srdeční frekvence, pořízený systémem VariaPulse TF-3 Sima Media

\section{Vyšetření funkční kapacity a řízená pohybová aktivita}

Vyšetření aerobní kapacity bylo provedeno $\mathrm{v}$ ranních hodinách vždy ve stejném čase před zařazením do studie a po absolvování dvanáctitýdenního tréninku. Symptomy limitované spiroergometrické vyšetření začínalo tř́minutovou adaptací vsedě na veloergometru. Následovaly zátěže od $20 \mathrm{~W}$, zvyšované po 2 minutách vždy o $20 \mathrm{~W}$, v jejichž průběhu byly měřeny ventilačně-respirační parametry (analyzátor plynů MedGraphics, USA) a zaznamenáván dvanáctisvodový elektrokardiogram (Schiller CS 100). V průběhu vyšetření byl stanoven anaerobní práh, který považujeme za relativně bezpečný limit intenzity aerobní zátěže. Hodnotili jsme $\mathrm{W}_{\text {peak }}(\mathrm{W})$ - vrcholový (maximální) dosažený výkon, $\mathrm{W}_{\text {peak }} \cdot \mathrm{kg}^{-1}\left(\mathrm{~W}^{\mathrm{kg}} \mathrm{kg}^{-1}\right)$ - vrcholový výkon přepočtený na $\mathrm{kg}$ tělesné hmotnosti, $\mathrm{VO}_{2 \text { peak }}\left(\mathrm{ml} \cdot \mathrm{min}^{-1}\right)$ - maximální př́ijem kyslíku na vrcholu zátěže, $\mathrm{VO}_{2 \text { peak }} \cdot \mathrm{kg}^{-1}\left(\mathrm{ml} \cdot \mathrm{min}^{-1} \cdot \mathrm{kg}^{-1}\right)$ - vrcholový př́ijem kyslíku vztažený na kg tělesné hmotnosti.

Pacienti absolvovali cvičení po dobu tř́ měsíců třikrát týdně na pracovištích Kliniky funkční diagnostiky a rehabilitace Lékařské fakulty Masarykovy univerzity Fakultní nemocnice u sv. Anny v Brně. V prvních dvou týdnech trénovali pouze aerobně. Cvičební jednotka trvala 60 min a skládala se z 10 min fáze zahřívací, 40 min aerobní zátěže na ergometru do intenzity anaerobního prahu (stanoveného dle vstupního spiroergometrického vyšetření), následovalo 10 min fáze uvolnění. Po dvou týdnech se cvi- 
čební jednotka sestávala z 10 min fáze zahřívací, 20 min fáze aerobní na ergometru, 20 min fáze posilování na kombinovaném posilovacím trenažéru (TK-HC COMPACT) cvičením sestavy tří cviků, 10 min fáze uvolnění. Intenzita zátěže ve fázi cvičení s posilovacími prvky byla stanovena metodou „jednou opakovatelného maxima“ (one repetition maximum, 1-RM) do jeho 60\%. Při spiroergometrickém vyšetření po ukončení rehabilitačního programu jsme hodnotili základní parametry výkonnosti a aerobní zdatnosti.

\section{Statistická analýza}

Pro statistické zpracování byl použit program Microsoft Excel pro Windows a program Statistica, verze 6.1. Pro porovnání dvou závislých proměnných použito Wilcoxonova testu. Změny byly hodnoceny jako statisticky významné př̀i hladině významnosti menší než 0,05 .

\section{VÝSLEDKY}

Dvanáctitýdenní kombinovaný (vytrvalostní/silový) trénink vedl u pacientů s chronickou ischemickou chorobou srdeční ke statisticky významnému zvýšení parametrů tělesné výkonnosti a aerobní zdatnosti (Tab. 1) .

Došlo ke zvýšení variability srdeční frekvence, změny TP, LF a HF dosáhly statistické významnosti (Tab. 2).

Tab. 1 Parametry výkonnosti a aerobní zdatnosti

\begin{tabular}{|c|c|c|c|c|}
\hline $\mathbf{n}=\mathbf{3 1}$ & $\begin{array}{c}\mathbf{W}_{\text {peak }} \\
(\mathbf{W})\end{array}$ & $\begin{array}{c}\mathbf{W}_{\text {peak }} \cdot \mathbf{k g}^{-1} \\
\left(\mathbf{W . k g}^{-1}\right)\end{array}$ & $\begin{array}{c}\mathbf{V O}_{2 \text { peak }} \\
\left(\mathbf{m l . m i n}^{-1}\right)\end{array}$ & $\begin{array}{c}\mathbf{V O}_{2 \text { peak }} \cdot \mathbf{k g}^{-1} \\
\left(\mathbf{m l} \cdot \mathbf{m i n 1} \cdot \mathbf{k g}^{-1}\right)\end{array}$ \\
\hline Před tréninkem & $109 \pm 37$ & $1,3 \pm 0,5$ & $1498 \pm 393$ & $18,2 \pm 5,9$ \\
\hline Po tréninku & $120 \pm 33^{\star}$ & $1,5 \pm 0,5^{*}$ & $1632 \pm 290^{*}$ & $20,3 \pm 4,3^{*}$ \\
\hline
\end{tabular}

Vysvětlivky

$\mathrm{W}_{\text {peak }}(\mathrm{W})$-vrcholový (maximální) dosažený výkon

$\mathrm{W}_{\text {peak }} \cdot \mathrm{kg}^{-1}\left(\mathrm{~W} \cdot \mathrm{kg}^{-1}\right)$ - vrcholový výkon přepočtený na kg tělesné hmotnosti

$\mathrm{VO}_{2 \text { peak }}\left(\mathrm{ml} . \mathrm{min}^{-1}\right)$ - maximální př́ijem kyslíku na vrcholu zátěže

$\mathrm{VO}_{2 \text { peak }} \cdot \mathrm{kg}^{-1}\left(\mathrm{ml} \cdot \mathrm{min}^{-1} \cdot \mathrm{kg}^{-1}\right)$ - vrcholový př́ijem kyslíku vztažený na kg tělesné hmotnosti.

* -- statisticky významné při hladině významnosti menší než 0,05 .

Tab. 2 Výsledky spektrální analýzy variability srdeční frekvence

\begin{tabular}{|l|c|c|c|}
\hline $\mathbf{n}=\mathbf{3 1}$ & Před RHB programem & Po RHB programu & Statistická významnost \\
\hline TP $\left(\mathrm{ms}^{2}\right)$ & $642 \pm 827$ & $1802 \pm 6265$ & $\mathbf{p}=\mathbf{0 , 0 4}$ \\
\hline LF $\left(\mathrm{ms}^{2}\right)$ & $163 \pm 198$ & $432 \pm 1094$ & $\mathbf{p}=\mathbf{0 , 0 4 7}$ \\
\hline HF $\left(\mathrm{ms}^{2}\right)$ & $472 \pm 684$ & $1371 \pm 2244$ & $\mathbf{p}=\mathbf{0 , 0 2 0}$ \\
\hline LF/HF & $0,83 \pm 0,91$ & $0,83 \pm 1,0$ & $\mathrm{p}=0,64$ \\
\hline MSSD $\left(\mathrm{ms}^{2}\right)$ & $1465 \pm 1530$ & $3825 \pm 6265$ & $\mathrm{p}=0,1$ \\
\hline RR $(\mathrm{s})$ & $1,06 \pm 0,15$ & $1,09 \pm 0,15$ & $\mathrm{p}=0,7$ \\
\hline
\end{tabular}

Vysvětlivky:

TP $\left(\mathrm{ms}^{2}\right)$ - celkový spektrální výkon (total power);

LF $\left(\mathrm{ms}^{2}\right)$ - spektrální výkon nízkofrekvenční komponenty $(0,0--0,15 \mathrm{~Hz})$;

$\mathrm{HF}\left(\mathrm{ms}^{2}\right)$ - spektrální výkon vysokofrekvenční komponenty $(0,15-0,4 \mathrm{~Hz})$;

LF/HF - poměr nízkofrekvenčního a vysokofrekvenčního spektrálního výkonu;

$\operatorname{MSSD}\left(\mathrm{ms}^{2}\right)$ - průměrná hodnota druhých mocnin rozdílů délek sousedních RR intervalů;

$\mathrm{RR}$ - průměrná délka R-R intervalů; 


\section{Diskuse}

Srdeční frekvence se v průběhu 24 hodin periodicky mění především v závislosti na vlivu sympatického a parasympatického autonomního nervového systému na sinusový uzel. Analýza variability srdeční frekvence spočívá v detailní analýze délek R-R intervalů EKG záznamu. V praxi hodnotíme krátkodobé záznamy trvající přibližně 5-20 minut při použití zvláštních monitorovacích a vyhodnocovacích systémů nebo záznamy dlouhodobé 24-48hodinové, v nichž se odráží celodenní aktivity vyšetřovaného jedince. Dlouhodobé záznamy jsou většinou součástí holterovských technik monitorace srdečního rytmu. Vlastní hodnocení variability srdeční frekvence lze provést dvěma způsoby. Statistickým zpracováním souboru všech $\mathrm{R}-\mathrm{R}$ intervalů $\mathrm{v}$ daném časovém úseku - časovou analýzou nebo spektrální analýzou série následných R-R intervalů - frekvenční analýzou. Při vyšetření spektrální analýzou můžeme hodnotit 3 hlavní komponenty srdeční frekvence. Velmi pomalou frekvenci (VLF=0,01-0,05 Hz), která se pravděpodobně vztahuje $\mathrm{k}$ termoregulační sympatické aktivitě cév, $\mathrm{k}$ hladině cirkulujících katecholaminů a k oscilacím v renin-angiotenzinovém systému. Nízká frekvence $(\mathrm{LF}=0,05-0,15)$ je nejvíce ovlivněna baroreflexní sympatickou a parasympatickou aktivitou a pomalými oscilacemi arteriálního krevního tlaku. Vysoká frekvence ( $\mathrm{HF}=0,15-0,5 \mathrm{~Hz}$ ) koresponduje s periodicitou dýchání a s tonem vagu (Novotný 1998). Celkový výkon do značné míry kopíruje dynamiku závislosti výkonů v oblasti nízkých a vysokých frekvencí, nikoliv VLF (Novotný 2000). Frekvenční pásma se však vzájemně překrývají a jsou proměnlivá $\mathrm{v}$ čase $\mathrm{u}$ každého jedince. Proto zatím nelze analýzu HRV použít jako specifickou metodu v diferenciální diagnostice jednotlivých onemocnění (Novotný 2003). Autonomní nervový systém je trvale vystaven řadě podnětů vnitřního i zevního prostředí. $Z$ vnitřních podnětů je to především věk a zdravotní stav jedince, $\mathrm{z}$ vnějších pak klimatické vlivy, denní doba, aktuální psychická a fyzická zátěž, ale i změny polohy těla. Pro usnadnění interpretce nálezů byla zavedena zkouška leh-stoj-leh, při níž se stř́ídá vleže převaha aktivity vagu s převahou sympatiku vstoje. Po opakovaném položení se dokonce projevuje „přestřelení“ hodnoty spektrálního výkonu vysokofrekvenční složky spektrální analýzy srdeční frekvence (overshoot). Proto se pro co nejpřesnější zhodnocení aktivity vagu doporučuje hodnocení spektrálních ukazatelů až z opakované polohy vleže (Opavský 2004). Na našem pracovišti toto doporučení respektujeme. Amplituda respirační arytmie je výrazně závislá na frekvenci a hloubce dýchání, tam, kde není frekvence dýchání kontrolována, může dojít ve variabilitě srdeční frekvence při vysoké frekvenci dýchání $\mathrm{k}$ nepredikovatelným změnám. Hluboké, pomalé dýchání o frekvenci 6 cyklů za minutu vede k posunu vrcholu respiračního spektra do oblasti $0,1 \mathrm{~Hz}$, a může tak imitovat zvýšení sympatické modulace srdečního rytmu (Kautzner 1998). V naší studii jsme proto hodnotili pětiminutové záznamy variability srdeční frekvence při metronomem kontrolovaném dýchání o frekvenci $0,33 \mathrm{~Hz}$.

Porucha funkce kteréhokoliv orgánu nebo systému, který se podílí na regulaci srdeční frekvence, se projeví změnou HRV. Nízká variabilita srdeční frekvence je známkou zvýšení rizika náhlé srdeční smrti po infarktu myokardu i u pacientů s chronickým srdečním selháním (La Rovere 1998, Semrád 1998, Galinier 2000, Hohnloser 1999). Tyto poznatky jsou důvodem pro pokusy modifikovat tento rizikový faktor tělesným cvičením.

Vyšetřování variability srdeční frekvence se $\mathrm{v}$ poslední době stalo předmětem četných klinických studií. Wolf a spolupracovníci upozornili již v roce 1978 na skutečnost, že pacienti s akutním infarktem myokardu a sníženou respirační arytmií mají v průběhu hospitalizace vyšší úmrtnost (Wolf 1978). Později byl zkoumán i vzájemný vztah mezi variabilitou srdeční frekvence a fyzickým cvičením u nemocných po akutním infarktu myokardu. I krátkodobý tréninkový program zlepšil pokleslou variabilitu (La-Rovere 1992). Změny variability srdeční frekvence byly v souvislosti s fyzickým tréninkem popsány u nemocných se srdečním selháním (Coats 1992). Ke zlepšení variability srdeční frekvence došlo i v naší studii s menším počtem pacientů s chronickou ischemickou chorobou srdeční a s reverzibilní ischemií myokardu prokázanou metodou fotonové emisní počítačové tomografie-SPECT (Jančík 2002). Je známo a bylo opakovaně potvrzeno, že pravidelné cvičení v rámci sekundární prevence ICHS zvyšuje variabilitu srdeční frekvence (Nolan 2008). Méně pozornosti je v literatuře věnováno možnému odlišnému vlivu vytrvalostního cvičení od tréninku silového. 
Adaptace kardiovaskulárního systému na silový trénink se liší od adaptace na trénink dynamický. Srdce silově trénujících vykazuje koncentrickou hypertrofii, naproti tomu adaptace srdce na vytrvalostní trénink je charakterizována zvětšením všech srdečních dutin a méně ztluštěním stěn. $V$ tomto případě je hypertrofie pokládána za excentrickou (Máček 1995). Vytrvalostní trénink vede oproti silovému k výraznějšímu snížení klidové tepové frekvence, systolického krevního tlaku v klidu, zvýšení tepového objemu v klidu i při zátěži (Pollock 2000). Lze tedy předpokládat i možný rozdílný efekt odlišných typů zátěže na variabilitu srdeční frekvence.

Ani samotný vytrvalostní trénink zřejmě nemusí vždy vést $\mathrm{k}$ ovlivnění variability srdeční frekvence. Perini se spolupracovníky měřili u pacientů starších 70 let srdeční frekvenci, tlak a variabilitu srdeční frekvence před a po osmitýdenním tréninku. Klidová srdeční frekvence a VSF zůstávaly nezměněny, zatímco hodnoty systémového tlaku poklesly (Perini 2002). V naší práci kombinace vytrvalostního cvičení s posilovacími cviky vedla po dvanáctitýdenním tréninku u mužů s kompenzovanou chronickou ischemickou chorobou srdeční ve fázi stabilizace ke zvýšení variability srdeční frekvence. Změny TP, LF a HF dosáhly statistické významnosti.

Neměnící se poměr výkonu v oblasti nízkých frekvencí k výkonu vysokofrekvenčního pásma spektra spolu se statisticky nevýznamným prodloužením R-R intervalu a nevýznamnými změnami MSSD mohou svědčit pro ovlivnění variability srdeční frekvence ve smyslu modulace vlivu obou větví autonomního nervového systému.

\section{ZÁVĚR}

Dvanáctitýdenní kombinovaný trénink vedl u mužů s chronickou ischemickou chorobou srdeční ke statisticky významnému zlepšení parametrů tělesné výkonnosti a aerobní zdatnosti. Došlo ke zvýšení variability srdeční frekvence, změny TP, LF a HF dosáhly statistické významnosti.

\section{Literatura}

CHALOUPKA, V., ELBL, L., NEHYBA, S. et al.: Pohybová aktivita u nemocných s kardiovaskulárním onemocněním. Kardiologická revue, 2003, č.1, s.16-20. ISSN 1212-4540.

COATS, A.J.S.: Exercise rehabilitation in chronic heart failure. J Am Col Cardiol, 1993, 22, Suppl. 172A-177A. ISSN 0735-1097.

GALINIER, M., PATHAK, A., FOURCADE, J., et al.: Depressed low frequency power of heart rate variability as an independent predictor of sudden death in chronic heart failure. Eur Heart J, 2000, roč. 21, s. 475-482. ISSN 0195-668X.

HOHNLOSER, S.H., KLINGENHEBEL, T., ZABEL, M.: Identification of patients after myocardial infarction at risk of life-threatening arrhythmias. Eur Heart J. Suppl., 1999, č.1, s. 11-20. ISSN 1520-765X. HULL, S.S., JR, VANOLI, E., ADAMSON, P.B., VERRIER, R.L., et al.: Exercise training confers anticipatory protection from sudden death during acute myocardial infarction. Circulation, 1994, roč.8, s.548552. ISSN 0009-7322.

JANČÍK, J., VÁRNAYOVÁ L., SIEGELOVÁ J. et al.: Heart rate variability in patients with chronic ischemic heart disease: effect of 8-week exercise training. In Proceedings of symposium The importance of chronobiology in diagnosing and therapy of internal diseases. Brno, IDVPZ, 2002, s.179-184. ISBN 80-7013-352-X.

KAUTZNER, J., MALIK, M.: Variabilita srdečního rytmu a její klinická použitelnost. Cor Vasa, 1998, roč. 40, č. 5, s. 244-251. ISSN 0032-6739.

LA-ROVERE, M.T, MORTARA, A., SYNDROME, G., LOMBARDI, F.: Autonomic nervous system adaptation to short-term exercise training. Chest 1992, roč.101, s. 299-303. ISSN 0012-3692.

LA-ROVERE, M.T., BIGGER, J.T., MARCUS, F.I., MORTARA, A., SCHWARTZ, P.J.: Baroreflex sensitivity and heart-rate variability in prediction of total cardiac mortality after myocardial infarction. Lancet, 1998, roč. 351, s. 478-484. ISSN 0140-67306. 
LEE, C.M., ELLIS, D., DAPRILE, D.M.: Cardiac autonomic modulation following high-intensity static muscle contraction. Am J Med Sci. 2006, roč.332, č.1, s. 6-12. ISSN 0002-9629.

MÁČEK, M., MÁČKOVÁ, J.: Fyziologie tělesných cvičení. Praha: Sdružení pro rozvoj zdravotní a tělesné výchovy ve spolupráci s Nakladatelstvím ONYX, 1995, ISBN 80-85228-20-3.

NOLAN, R., JONG, P., BARRY-BIANCHI, S. et al.: Effects of drug, biobehavioral and exercise therapies on heart rate variability in coronary artery disease: a systematic review. European Journal of Cardiovascular Prevention \& Rehabilitation 2008, 15: 386-396.

NOVOTNÝ, J., SEBERA, M., HRAZDIRA, L., NOVOTNÁ, M.: Kapitoly sportovní medicíny. Brno: Paido, 2003, CD: ISBN 80-7315-064-6.

NOVOTNÝ, J., HRSTKOVÁ, H., DOHNALOVÁ, I., HLAVOŇOVÁ, D.: Variabilita srdeční frekvence při posuzování schopnosti k pohybové aktivitě u dětí a mladistvých po léčbě cytostatiky. In: 5. mezinárodní sympozium o zdraví sportovců a zdravém způsobu života, Brno, Agentura MedVěd, 2000, s. 138-141. ISBN 80-238-4667-1.

NOVOTNÝ, J., KOLKOVÁ, E., SLÁDKOVÁ, H., DOJČÁROVÁ, L., DOHNALOVÁ, I.: Variabilita srdeční frekvence u zdravých dětí vleže. Med Sport Boh Slov, 1998, roč. 7, č. 2, str. 35-40. ISSN 1210-5481.

OKAZAKI, K., IWASAKI, K., PRASAT, A.: Dose-response relationship of endurance training for autonomic circulatory control in healthy seniors. J Appl Physiol, 2005, roč. 99 č.3, s. 1041-1049. ISSN 0021-8987. OPAVSKÝ, J.: Metody vyšetřování autonomního nervového systému a spektrální analýza variability srdeční frekvence v klinické praxi. In: Salinger, J. Variabilita srdeční frekvence a její hodnocení v biomedicínckých oborech-od teorie ke klinické praxi. Sborník článků a abstrakt. Olomouc, Univerzita Palackého v Olomouci, 2004. ISBN 80-244-0805-8.

PERINI, R., FISCHER, N., VEICSTEINAS, A. et al. Aerobic training and cardiovascular response at rest and dutiny exercise in older men and women. Med Sci Sports Exerc, 2002, roč. 34, č. 4, s. 700-708. ISSN 0195-9131.

POLLOCK, M. L., FRANKLIN, B. A., BALADY, G. J. et al.: Resistance Exercise in Individuals With and Without Cardiovascular Disease. Benefits, Rationale, Safety, and Prescription. An Advisory From the Comittee on Exercise, Rehabilitation, and Prevention, Council on Clinical Cardiology, American Heart Association. Circulation, 2000 roč. 101, s. 828-833. ISSN 0009-7322.

REZK, C.C., MARRACHE, R.C., TINUCCI, T., MION, D. JR., FORJAZ, C.L: Post-resistance excercise hypotension, hemodynamics, and heart rate variability: influence of excercise intensity. Eur J Appl Physiol., 2006, roč. 98, č.1, s.105-112. ISSN 1439-6319.

SEMRÁD, B., FIŠER, J., HONZÍKOVÁ, N.: Aging and cardiac autonomic status. In: (ed. Malik, M.) Clinical Guide to cardiac autonomic test. London, Kluwer Academic Publishers, 1998, s. 285-300.

WOLF M.W., VARIGOS, G.A., HUNT, D. et al:. Sinus arrhytmia in acute myocardial infarction. Med J Austral, 1978, č. 2, s. 52-53. ISSN 0025-729X. 